\title{
Propofol Alters Long Non-Coding RNA Profiles in the Neonatal Mouse Hippocampus: Implication of Novel Mechanisms in Anesthetic-Induced Developmental Neurotoxicity
}

\author{
Sarah Logan ${ }^{\mathrm{a}, \mathrm{b}}$ Congshan Jiang ${ }^{c}$ Yasheng Yan ${ }^{\mathrm{a}}$ Yasuyoshi Inagaki ${ }^{\mathrm{d}}$ \\ Thiago Arzua ${ }^{\mathrm{a}, \mathrm{b}} \quad$ Xiaowen Bai ${ }^{\mathrm{a}}$ \\ aDepartment of Cell Biology, Neurobiology \& Anatomy, Medical College of Wisconsin, ${ }^{b}$ Department \\ of Physiology, Medical College of Wisconsin, Milwaukee, USA, 'Department of Biochemistry and \\ Molecular Biology, School of Basic Medical Science, Xi'an Jiaotong University Health Science Center, \\ China, dDepartment of Emergency Medicine, Nayoro City General Hospital, Japan
}

\section{Key Words}

Apoptosis $\bullet$ Developmental neurotoxicity $\bullet$ Long non-coding RNAs $\bullet$ Microarray $\bullet$ Bioinformatics analysis

\footnotetext{
Abstract

Background: Propofol induces acute neurotoxicity (e.g., neuroapoptosis) followed by impairment of long-term memory and learning in animals. However, underlying mechanisms remain largely unknown. Long non-coding RNAs (IncRNAs) are found to participate in various pathological processes. We hypothesized that IncRNA profile and the associated signaling pathways were altered, and these changes might be related to the neurotoxicity observed in the neonatal mouse hippocampus following propofol exposure. Methods: In this laboratory experiment, 7-day-old mice were exposed to a subanesthetic dose of propofol for 3 hours, with 4 animals per group. Hippocampal tissues were harvested 3 hours after propofol administration. Neuroapoptosis was analyzed based on caspase 3 activity using a colorimetric assay. A microarray was performed to investigate the profiles of 35,923 IncRNAs and 24,881 messenger RNAs (mRNAs). Representative differentially expressed IncRNAs and mRNAs were validated using reverse transcription quantitative polymerase chain reaction. All mRNAs dysregulated by propofol and the 50 top-ranked, significantly dysregulated IncRNAs were subject to bioinformatics analysis for exploring the potential mechanisms and signaling network of propofol-induced neurotoxicity. Results: Propofol induced neuroapoptosis in the hippocampus, with differential expression of 159 IncRNAs and 100 mRNAs (fold change \pm

S. Logan and C. Jiang contributed equally to this work.

\begin{tabular}{ll}
\hline Xiaowen Bai & Department of Cell Biology, Neurobiology \& Anatomy, Medical College of Wisconsin \\
& 8701 Watertown Plank Road, Milwaukee, WI 53226 (USA) \\
E-Mail xibai@mcw.edu
\end{tabular}
}




\section{Cellular Physiology Cell Physiol Biochem 2018;49:2496-2510 and BiOChemistry Published onIme: 28 September $2018 \begin{aligned} & \text { DO } 2018 \text { The Author(s). Published by S. Karger AG, Basel } \\ & \text { www.karger.com/cpb }\end{aligned}$ \\ Bai et al.: IncRNAs and Propofol Developmental Neurotoxicity}

2.0, $\mathrm{P}<0.05)$. Bioinformatics analysis demonstrated that these IncRNAs and their associated mRNAs might participate in neurodegenerative pathways (e.g., calcium handling, apoptosis, autophagy, and synaptogenesis). Conclusion: This novel report emphasizes that propofol alters profiles of IncRNAs, mRNAs, and their cooperative signaling network, which provides novel insights into molecular mechanisms of anesthetic-induced developmental neurodegeneration and preventive targets against the neurotoxicity.

(C) 2018 The Author(s)

Published by S. Karger AG, Basel

\section{Introduction}

Propofol is one of the most commonly used pediatric anesthetics. Mounting evidence from animal studies has demonstrated that propofol induces neuronal death followed by cognitive dysfunction (e.g., impaired learning and memory ability) that are persistent into adulthood in animal models [1-7]. The observed neurotoxicity was specific to the brain growth spurt during the developmental period [8-12]. Since many developmental events such as neurogenesis and synaptogenesis occur during this period, neuronal death may not be the only consequence of propofol exposure. Several abnormal changes, such as decreased neural stem cell proliferation, altered neurogenesis, neurite retraction, and dendrite growth reduction, have already been demonstrated [13-16]. So far, cellular and molecular events altered by propofol, such as intracellular calcium levels, neurotrophin expression, mitochondrial signaling (e.g., mitochondrial fission) have been identified as potential contributors to this neurodevelopmental dysfunction [3, 12, 17-19]. However, the detailed mechanisms by which this toxicity occurs in developmental brains remain largely unknown. Additionally, the findings that propofol can attenuate cellular injury in other types of cells (e.g. cardiomyocytes and liver cells) $[20,21]$ call for greater understanding as to why propofol is specifically harmful to the developing brain.

Long non-coding RNAs (lncRNAs) are composed of at least 200 nucleotides. So far, over 30, 000 lncRNAs have been identified; however, very few of these lncRNAs have been characterized for their functions and underlying mechanisms [22]. IncRNAs are rapidly emerging as major regulators of cellular and molecular events. IncRNA profiles and lncRNA/ messenger RNA (mRNA) interactions have been implicated as spatially and temporally dynamic during neurogenesis [23], making them interesting candidates with underlying neurotoxic phenotypes resulting from developmental anesthetic exposure. One recent study indicates the important roles of IncRNAs in anesthetic neurotoxicity. The authors found that brain-derived neurotrophic factor antisense (BDNF-AS) IncRNA was upregulated by the intravenous anesthetic agent ketamine in cultured mouse stem cell-derived neurons. BDNF-AS-induced downregulation of BDNF decreased neurite growth and increased apoptosis [24]. The effort of this study focused on a single lncRNA dysregulated by ketamine; however, the role of IncRNAs in propofol-induced development has not been explored yet. We hypothesized that IncRNA profile and the associated signaling pathways were altered, and these changes might be related to the neurotoxicity observed in the neonatal mouse hippocampus following propofol exposure.

Thus, the current study profiles dysregulated lncRNAs and mRNAs in the hippocampus (a brain region associated mainly with memory) from propofol-treated 7-day-old mice relative to control mice. Based on differentially expressed lncRNAs and mRNAs between propofol and control groups, we performed bioinformatics analysis of mRNA involvement, lncRNA/ mRNA interaction, and proposed cellular and molecular signaling networks that might be related to initiation and progression of neurodegeneration following propofol exposure. 


\section{Cellular Physiology Cell Physiol Biochem 2018;49:2496-2510 \begin{tabular}{ll|l} 
and Biochemistry Published onIIne: 28 September 2018 & $\begin{array}{l}\text { (c) } 2018 \text { The Author(s). Published by S. Karger AG, Basel } \\
\text { www.karger.com/cpb }\end{array}$ \\
\hline
\end{tabular}}

Bai et al.: IncRNAs and Propofol Developmental Neurotoxicity

\section{Materials and Methods}

\section{Animal studies}

All studies were approved by the Institutional Animal Care and Use Committee at the Medical College of Wisconsin. C57BL/6 mice were obtained from Jackson Laboratories (Bar Harbor, ME). The greatest vulnerability of the developing brain to anesthetics occurs within the first 2 postnatal weeks, peaking at approximately postnatal day 7 [25]. Thus, 7-day-old mice were used for the current study.

\section{Anesthetic exposure}

Mice were exposed to propofol (ZOETIS) or the vehicle control 10\% intralipid (Fresenius Kabi AB) for 3 hours. The dose of propofol intraperitoneally injected was $50 \mathrm{mg} / \mathrm{kg}$. This dose of propofol was selected based on previous reports showing that 1) the dosage required to induce a surgical plane of anesthesia in mice was $200 \mathrm{mg} / \mathrm{kg}$, and 2) sub-anesthetic doses of 50 and $100 \mathrm{mg} / \mathrm{kg}$ propofol triggered neuroapoptosis. It was also reported that single intraperitoneal injection of propofol maintained anesthesia in mice for approximately 90 minutes [26]. Therefore, we administered propofol every 90 minutes throughout the experiments for a total of 2 times. Following injection, animals were placed on a heated pad $\left(37^{\circ} \mathrm{C}\right)$. Mice were euthanized 3 hours following 3-hour propofol exposure for further tissue harvest used for Western blot analysis and lncRNA and mRNA profile assay of the hippocampus.

\section{Caspase 3 activity assay}

Caspase 3 enzyme activity assay was analyzed using a Caspase 3 Colorimetric Assay Kit (Sigma Aldrich, MO, USA). Briefly, the caspase 3 activities in the cell lysate were analyzed by administration of the caspase 3 substrate acetyl-Asp-Glu-Val-Asp p-nitroanilide (Ac-DECD-pNA) and incubated for 90 minutes. The concentration of the reaction product pNA was detected at $405 \mathrm{~nm}$ and caspase 3 enzyme activity was calculated using the following formula:

\section{$\frac{\mu \mathrm{mol} \text { caspase } 3 \text { reaction product } \times \text { dilution factor }}{\mathrm{ml}(\text { sample lysate }) \times \min (\text { reaction time }) \times \mathrm{mg}(\text { protein })} \times 100 \%$}

\section{RNA extraction}

RNA was extracted using a phenol-chloroform method as described in our previous publication [19]. The extracted RNA was used for microarray and reverse transcription-quantitative polymerase chain reaction (RT-qPCR) assays as described below.

\section{Microarray assay}

Mouse LncRNA Expression Microarray V3.0 assay and data analysis were performed by Arraystar Inc. (Rockville, MD) to evaluate global expression levels of 35, 923 lncRNAs and 24, 881 mRNAs in the hippocampus. Prior to the microarray assay, RNA was subject to RNA quality control analysis of RNA quantity, purity, integrity, and genomic DNA contamination and probe label efficiency. The RNA was converted to complementary DNA (cDNA) and then hybridized to Arraystar's custom IncRNA or mRNA probes. The significantly differentially expressed IncRNAs and mRNAs were defined by expressing above \pm 2.0 fold change and $p<0.05$ between propofol and control samples, and are shown in volcano plots or heatmaps. Volcano plot depicts the $p$-value against the fold change ratio, with genes with the largest magnitude fold change in abundance being most displaced from the center of the plot ( 0 on the X-axis). The heatmap shows the gene profile of all samples analyzed. Data were normalized by a $\log _{2}$ transformation of the fold change and $\mathrm{a}-\log _{10}$ transformation of the $p$-value.

\section{$R T-q P C R$}

In order to confirm the gene expression results obtained from the microarray, the expression level of 4 randomly selected differentially expressed lncRNA (Gm11985 and Ak156531) and mRNAs (Igfbp1 and Npas4) were further analyzed using RT-qPCR assay as shown in our previous publication [19]. Briefly, cDNA was synthesized using an RT2 First Strand Kit (Qiagen). For qPCR assay, cDNA was mixed with ${ }^{\text {TM }}$ SYBR Green Master Mix (Thermo Fisher Scientific), primers, and pure water (Qiagen). Triplicate samples were loaded 


\section{Cellular Physiology Cell Physiol Biochem 2018;49:2496-2510

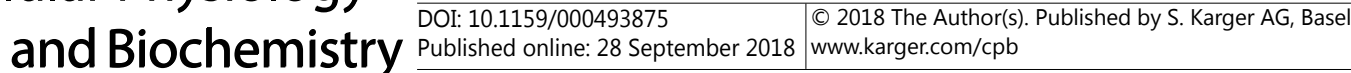

Bai et al.: IncRNAs and Propofol Developmental Neurotoxicity

into 96-well plates (25 $\mu \mathrm{l} /$ well) and RT-qPCR was performed using QuantStudio ${ }^{\mathrm{TM}} 6$ Real-Time PCR detection system (Thermo Fisher Scientific) for 10 minutes at $95^{\circ} \mathrm{C}$ followed by 40 cycles of a denaturation step (15 seconds at $\left.95^{\circ} \mathrm{C}\right)$ and a combined annealing/extension step $\left(30\right.$ seconds at $\left.60^{\circ} \mathrm{C}\right)$. The mean cycle threshold (Ct) values of triplicate wells for each sample were collected and the expression data was normalized to the endogenous control (beta-actin). Melting curves were monitored to validate the purity of the PCR product in each well.

Ingenuity Pathway Analysis of differentially expressed mRNAs and their associated signalling pathways

In order to study the possible mechanisms and signaling pathways of differentially expressed mRNAs in propofol-induced developmental neurotoxicity, we performed bioinformatics analysis of mRNAs using Ingenuity Pathway Analysis (IPA) software (Qiagen Bioinformatics). IPA performs a causal network analysis of gene involvement based on its known upstream regulators, downstream effects, and the gene's role in previously established pathways. The analysis reveals hypothetical disease mechanisms, toxicity pathways, and canonical physiological signaling pathways [27]. Based on IPA prediction of pathway clusters and involved genes from the Arraystar dataset, the selected pathways analyzed were associated with developmental anesthetic exposure and neurodegenerative phenotypes.

\section{Analysis of involved signaling pathways of differentially expressed IncRNAs}

Our data showed that there were 159 IncRNAs and 100 mRNAs dysregulated following propofol exposure. In this current study, we analyzed top-ranked 50 lncRNAs and all dysregulated mRNAs to predict IncRNA pathway using the following two bioinformatics analysis approaches as described in previous publications $[28,29]$. The top 50 lncRNAs were selected based on the criteria with $p<0.01$ and the highest absolute fold change value (propofol vs control). 1) lncRNA Gene Set Enrichment Analysis (lncRNA-GSEA) was used for analyzing the signaling pathways of IncRNAs and the roles of IncRNAs in developmental neurotoxicity. The correlation between the expression level of each top 50 lncRNA and all dysregulated mRNAs was analyzed. For each IncRNA, a list of correlation-based ranked mRNAs was constructed and subjected to GSEA. An association matrix between IncRNA and KEGG pathway was constructed using the value of |Normalized enrichment score| greater than 1 and a false-discovery rate (FDR) q-value threshold of 0.2. 2) IncRNA-mRNA co-expression interaction assay was used for analyzing the networks among lncRNAs and mRNAs. Correlation coefficients between the normalized data of the top 50 non-coding genes (lncRNA) and all dysregulated coding gene (mRNA) expression were calculated. mRNAs with the absolute value of Pearson correlation coefficients greater than 0.9 and FDR less than 0.05 were selected for generation of the coding and non-coding gene co-expression network map using the software Cytoscape V2.8.3. Literature searches for IncRNAs and mRNAs involved in neurodevelopmental and/or neurodegenerative conditions were performed by utilizing the National Center for Biotechnology Information Pubmed search engine, and searching for both gene name and gene abbreviation.

\section{Statistics}

The data were presented as mean \pm standard deviation (SD). All data from individual experiments were obtained from 4 intralipid- and 4 propofol-treated mice $(n=4)$, based on the previous data from our lab and similar studies in the field [30,31]. For differentially expressed lncRNAs and mRNAs by microarray, Western blot analysis of cleaved caspase 3, and RT-qPCR analysis of gene expression were done. An independent two-tailed t-test was performed using SPSS (IBM SPSS Statistics 24, USA) to compare the values between propofol and control groups; $p<0.05$ was considered statistically significant. Statistical analysis of the signaling pathway was described in the sections above.

\section{Results}

Propofol induces neuroapoptosis in the hippocampus

Propofol exposure for 3 hours induced 30\% increase of caspase 3 enzyme activity (an apoptosis indicator) in the hippocampus of P7 mice compared with mice exposed to the $10 \%$ intralipid vehicle control (Fig. 1). 
Fig. 1. Propofol induces neuroapoptosis in the 7-dayold mouse hippocampus by analysis of caspase 3 activity. $n=4$ samples per group; *: $\mathrm{p}<0.05$.
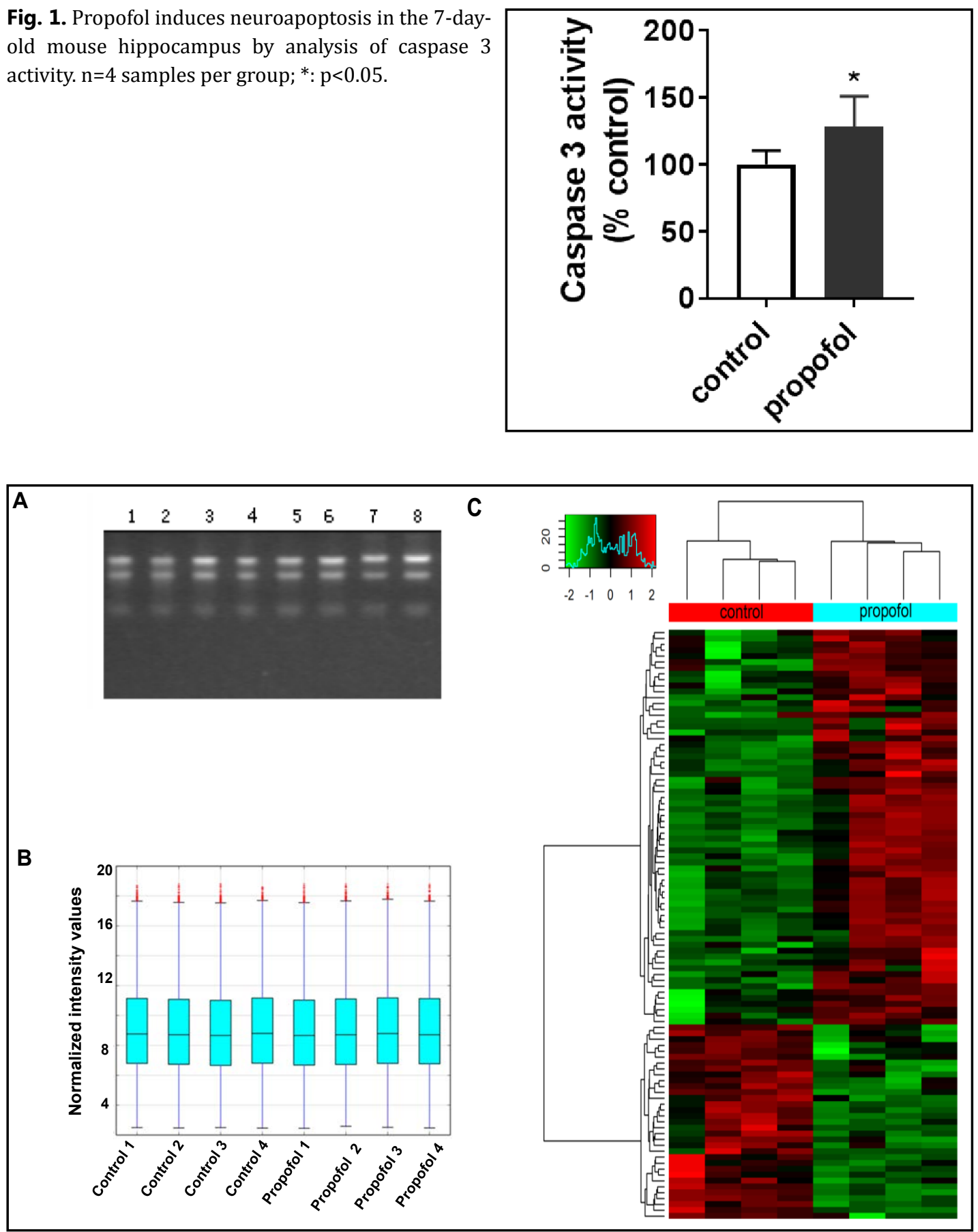

Fig. 2. Propofol alters messenger RNA (mRNA) profiles in the mouse hippocampus. (A) The images of denaturing agarose gel electrophoresis of total RNAs isolated from 4 intralipid- or 4 propofol-treated mouse hippocampal tissues. (B) The box plots display similar distributions of normalized mRNA intensity values across 4 control and 4 propofol samples, suggesting that the microarray data can be used for further analysis. Each box plot consists of a box with a central line and two tails. The central line represents the median of mRNA intensity values whereas the tails represent the upper and lower quartiles. (C) Heatmap showing profiles and the hierarchical clustering of differentially expressed mRNAs between intralipid- and propofol-treated mouse hippocampus $(n=4 ; p<0.05)$. The red signal refers to high relative expression and the green signal referred to low relative expression. 
Propofol induces the
alteration of mRNA
profiles

Each sample was confirmed to be suitable for microarray assay based on the RNA quantity, purity (data not shown), integrity, and appropriate probe label efficiency (Fig. 2A). The distribution of normalized intensity values between two groups indicated that these data were suitable for further analysis (Fig. 2B). Out of 24, $881 \mathrm{mRNA}$ transcripts, there were 67 upregulated mRNAs (propofol vs. control) and 33 downregulated (above \pm 2.0 fold change, $p<0.05$ ) as shown in the heatmap (Fig. 2C). The expression level of 2 representative altered mRNAs, Igfbp1 and Npas4, was further validated using RT-qPCR $\quad(p=0.019$ for Igfbp 1 and $p=0.021$ for Npas4; Fig. 3A) and the data were consistent with what obtained from microarray assay.
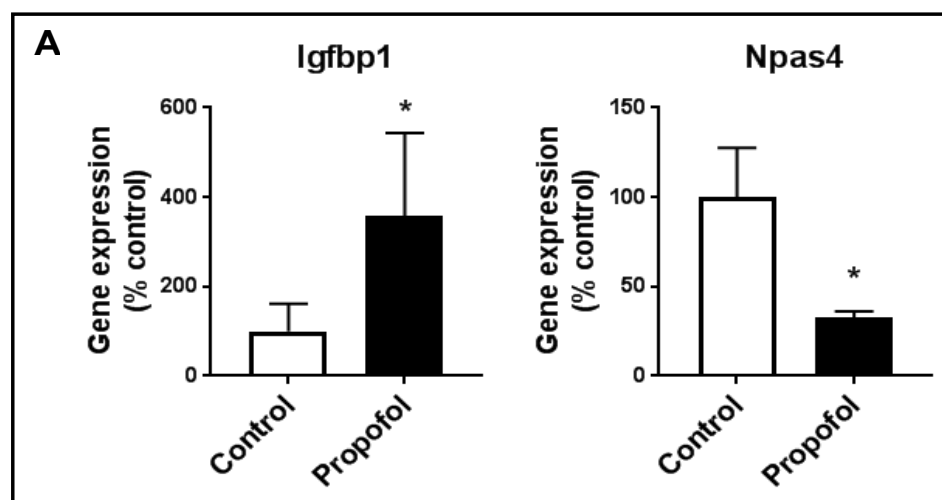

B
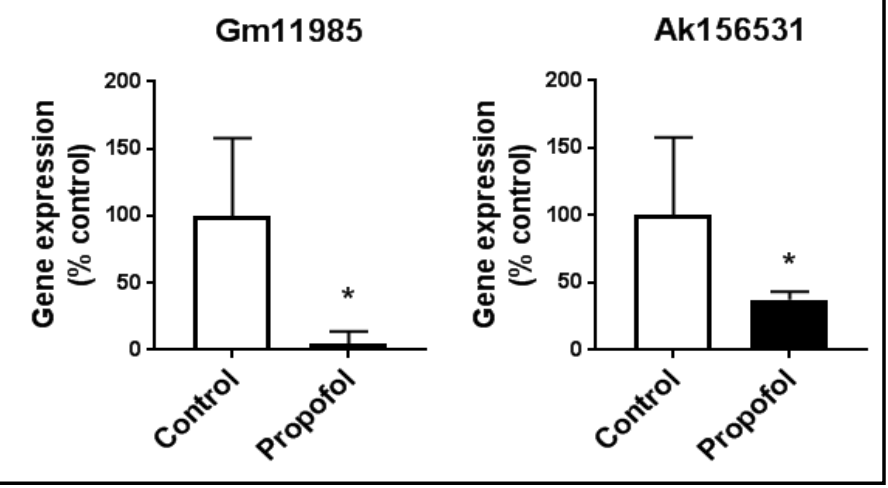

Fig. 3. (A) qRT-PCR validation of 2 representative altered mRNAs from array data (Igfbp1 and Npas4). ( $\left.\mathrm{n}=4 ;{ }^{*} \mathrm{p}<0.05\right)$. (B) qRT-PCR validation of two representative altered $\operatorname{lncRNAs}$ from array data. $\left(\mathrm{n}=4 ;{ }^{*} \mathrm{p}<0.05\right)$.

\section{Propofol induces the alteration of IncRNA profiles}

The general distribution of normalized intensity values between control and propofol groups was similar (Fig. 4A). The volcano plot illustrated the differentially expressed lncRNAs between control and propofol groups (Fig. 4B). Out of total 35, 923 IncRNA transcripts, there were 107 upregulated and 52 downregulated lncRNAs in the propofol versus control group as shown in the heatmap (above \pm 2.0 fold change, $p<0.05$ ) (Fig. 4C). Two representative altered lncRNAs (Gm11985 and Ak156531) from the microarray data were further validated using RT-qPCR (Fig. 3B) and the results were consistent with the array data ( $\mathrm{p}=0.034$ for Gm 11985 and $\mathrm{p}=0.021$ for Ak156531). Intergenic, exon sense-overlapping, natural antisense, intronic antisense, and bidirectional IncRNAs represent $50.6 \%, 22.7 \%, 12.2 \%, 11.7 \%$, and $2.8 \%$ of all 159 dysregulated lncRNAs, respectively (Fig. 4D). There were seven altered lncRNAs whose nearby coding genes (mRNAs) were also dysregulated following propofol treatment $(p<0.05$, fold change > \pm 2): Gm11985/Igfbp1, AK153212/Ly6c1, AK153212/Ly6a, AK156531/Npas4, AK156997/Tmem174, A730032A03Rik/Slpi and Gm3294/Fam71f1 (Table 1).

Propofol-induced altered mRNAs are involved in apoptosis and neurodegeneration signaling pathways

IPA software was used to analyze signaling pathways of the differentially expressed mRNA $( \pm 2.0$ fold cut-off $)$. Specifically, we selected the signalling pathways that were associated with 1) brain developmental events (e.g., synaptic plasticity), and 2) previouslydocumented anesthesia neurotoxicity phenotypes and cellular events (e.g., apoptosis and 


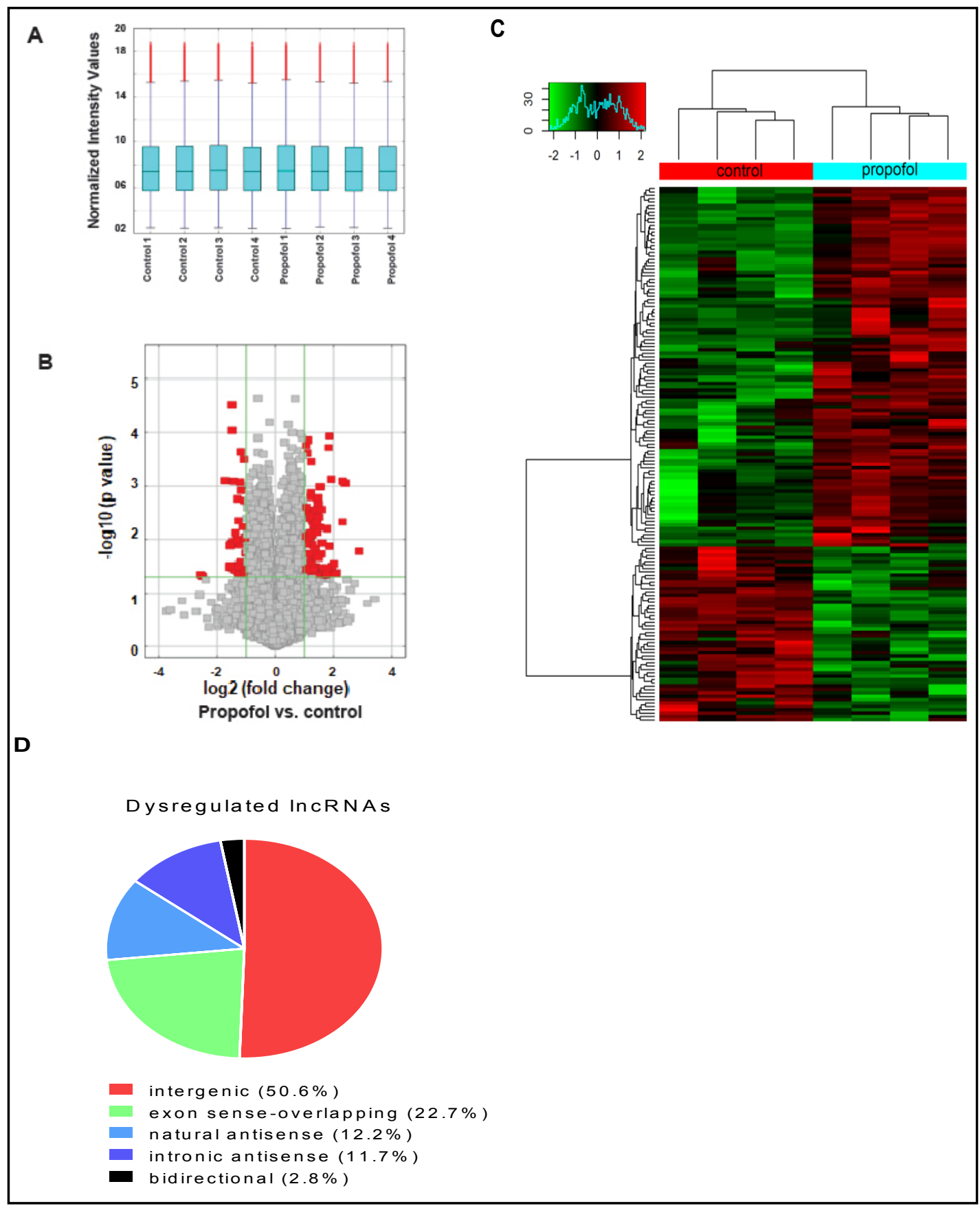

Fig. 4. Propofol alters profiles of long non-coding RNAs (lncRNAs) in the mouse hippocampus. (A) The box plots showing the similar distributions of normalized IncRNA intensity values from 4 control and 4 propofol samples. Each box plot consists of a box with a central line and two tails. The central line represents the median of IncRNA intensity values, whereas the tails represent the upper and lower quartiles. (B) The volcano plot illustrating the differentially expressed lncRNAs (red dots) between control and propofol groups. These altered lncRNAs were either downregulated (left red dots) or upregulated (right red dots) following propofol exposure. (C) Heat map showing the profiles and hierarchical clustering of differentially expressed lncRNAs in intralipid- and propofol-treated mouse hippocampus $(n=4 ; p<0.05)$. The red signals refer to high relative expression and the green signals indicate low relative expression. Among 24,881 lncRNAs analyzed, 159 IncRNAs were differentially expressed following propofol exposure. (D) Pie chart showing the ratio of various types of dysregulated lncRNAs. Specifically, over $50 \%$ total dysregulated lncRNAs were intergenic lncRNAs. 
Table 1. Propofol-induced individual dysregulated lncRNAs and their neighbor protein-coding genes which are also altered following propofol exposure. Note: chr is the abbreviated chromosome. P value and fold change is shown as propofol vs. control. Expression changes are shown compared with control group

\begin{tabular}{|c|c|c|c|c|c|c|c|c|c|c|}
\hline \multirow[t]{2}{*}{ IncRNA symbol } & \multirow[t]{2}{*}{ Genomic location of IncRNAs } & \multirow[t]{2}{*}{$\begin{array}{l}\text { IncRNA } \\
\text { p-value }\end{array}$} & $\begin{array}{c}\text { IncRNA } \\
\text { fold change }\end{array}$ & IncRNA change & \multirow[t]{2}{*}{ FDR } & \multirow[t]{2}{*}{ IncRNA's neighbor protein-coding gene symbol } & $\begin{array}{l}\text { mRNA } \\
\text { p-value }\end{array}$ & $\begin{array}{c}\text { mRNA } \\
\text { fold change }\end{array}$ & mRNA change & \multirow[t]{2}{*}{ FDR } \\
\hline & & & \multicolumn{2}{|c|}{ Propofol vs. control } & & & \multicolumn{3}{|c|}{ Propofol vs. control } & \\
\hline Gm11985 & chr11 & 0.036 & 2.2 & down & 0.59 & Igfbp1 & 0.005 & 3.7 & up & 0.52 \\
\hline AK153212 & chr15 & 0.004 & 2.3 & up & 0.42 & Ly6c1 & 0.040 & 2.2 & up & 0.72 \\
\hline AK153212 & chr15 & 0.004 & 2.3 & up & 0.42 & Ly6a & 0.007 & 2.0 & up & 0.54 \\
\hline AK156531 & chr19 & 0.008 & 2.6 & down & 0.45 & Npas4 & 0.001 & 4.2 & down & 0.40 \\
\hline AK156997 & chr13 & 0.039 & 2.1 & up & 0.59 & Tmem174 & 0.022 & 3.0 & up & 0.66 \\
\hline A730032A03Rik & chr2 & 0.042 & 2.7 & up & 0.61 & Slpi & 0.034 & 2.1 & up & 0.71 \\
\hline Gm3294 & chr6 & 0.031 & 2.9 & down & 0.58 & Fam71f1 & 0.015 & 3.4 & up & 0.62 \\
\hline
\end{tabular}

Fig. 5. Bioinformatics analysis of signaling pathways of propofolinduced altered mRNAs in the neonatal mouse hippocampus using IPA software. The selected pathways shown in the left column were associated with developmental anesthetic exposure and neurodegenerative phenotypes based on previous publications included in the IPA database. The right columnlists altered mRNAs that were associated with the signaling pathway shown in the left column. The green and red arrows, respectively, represent the mRNA downregulation or upregulation following propofol exposure.

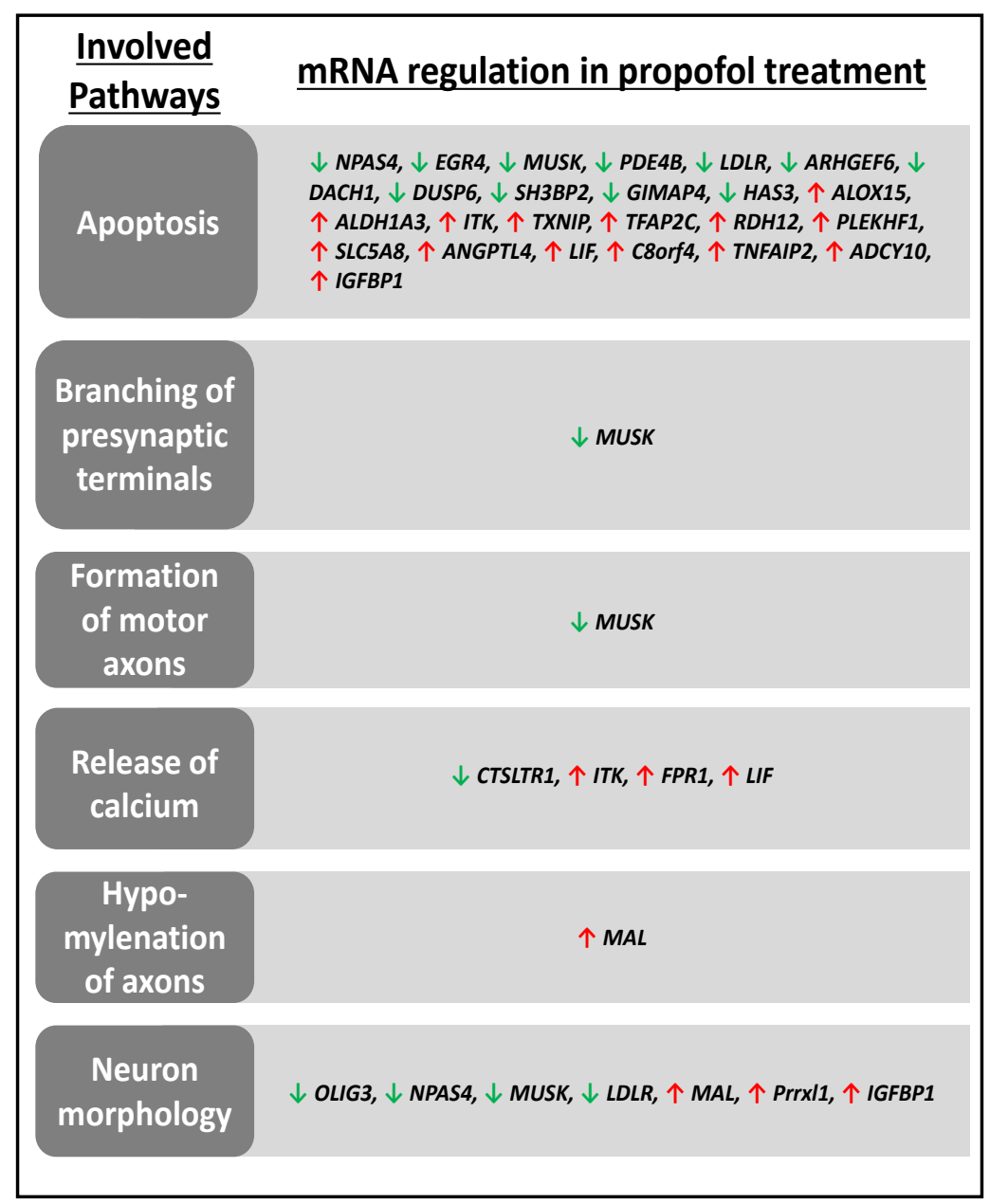

dysregulated calcium signaling). The respective dysregulated mRNA clusters influencing these physiological and pathological processes were listed in Fig. 5. For example, among the 25-dysregulated mRNAs that were reported to participate in the apoptosis process, 11 mRNAs were downregulated while another 14 mRNAs were upregulated in the propofoltreated hippocampus compared with the control group. 
Fig. 6. Bioinformatics analysis of neurodegenerative signaling pathways of top 50-ranked altered IncRNAs. The green and red arrows, respectively, representative IncRNA downregulation and upregulation following propofol exposure.

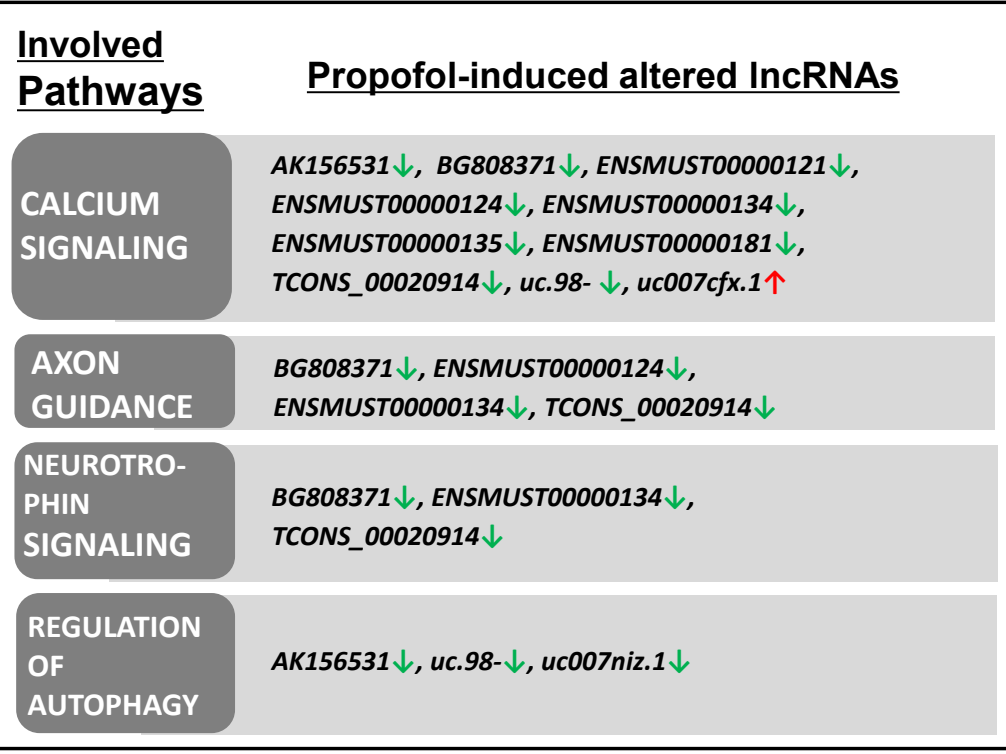

Propofol-induced Dysregulated IncRNAs possibly form extensive signaling networks with dysregulated mRNAs and might be associated with anesthetic-induced adverse outcomes in the developing hippocampus

lncRNA-GSEA analysis showed the top 50 dysregulated lncRNAs are associated with many physiology- and pathology-related signaling pathways. These lncRNAs were either positively or negatively correlated with individual signaling pathways (Supplementary Fig. S1) (for all supplementary material see www.karger.com/doi/10.1159/000493875). We further focused on analyzing neurotoxicity-related pathways and found that 14 dysregulated lncRNAs were significantly involved in calcium signaling, axon guidance, regulation of autophagy, neurotrophin signaling disease, and long-term depression (Fig. 6). To understand the lncRNA-associated mRNA interaction, the coding/non-coding gene coexpression network study was performed using the dysregulated top 50 lncRNAs and all dysregulated gene-coding mRNA. The results showed that there were many lncRNA-mRNA interaction pairs in the propofol-treated mouse hippocampus (Supplementary Fig. S2). There was no previously published literature on any of the 159 propofol-altered IncRNAs, while 22 of 100 dysregulated mRNAs were previously implicated in neurodevelopmental and neurodegenerative conditions (Table 2).

\section{Discussion}

In this study, we utilized IncRNA and mRNA profiling to predict lncRNA-involved signaling pathways in propofol-induced developmental neurotoxicity in the mouse hippocampus by bioinformatics analysis. We found increased neuroapoptosis that was concurrent with an altered abundance of $159 \mathrm{lncRNAs}$ and $100 \mathrm{mRNAs}$ in mouse hippocampal tissues $3 \mathrm{~h}$ following propofol $(3 \mathrm{~h})$ exposure. These data suggest that a short-term propofol exposure induces significant changes of lncRNA and mRNA profiles. These dysregulated lncRNAs, mRNAs, and respective interactions between them may be related to several signaling pathways (e.g., calcium and synaptic plasticity) that were previously nominated for their involvement in anesthetic neurotoxicity. In addition to the neuroapoptosis observed in our study (Fig. 1), several reports suggest other propofol-induced side effects (e.g., dysregulated neurogenesis, abnormal dendritic development, and decreased neurotrophic factor expression) $[12,18,19$, $30,32,33]$. Thus, the current study on the analysis of the signaling pathways based on altered IncRNA and mRNA involvement was not limited to focus on apoptosis alone but predicted pathways linked to multiple neurological outcomes. This opens more doors to study various 


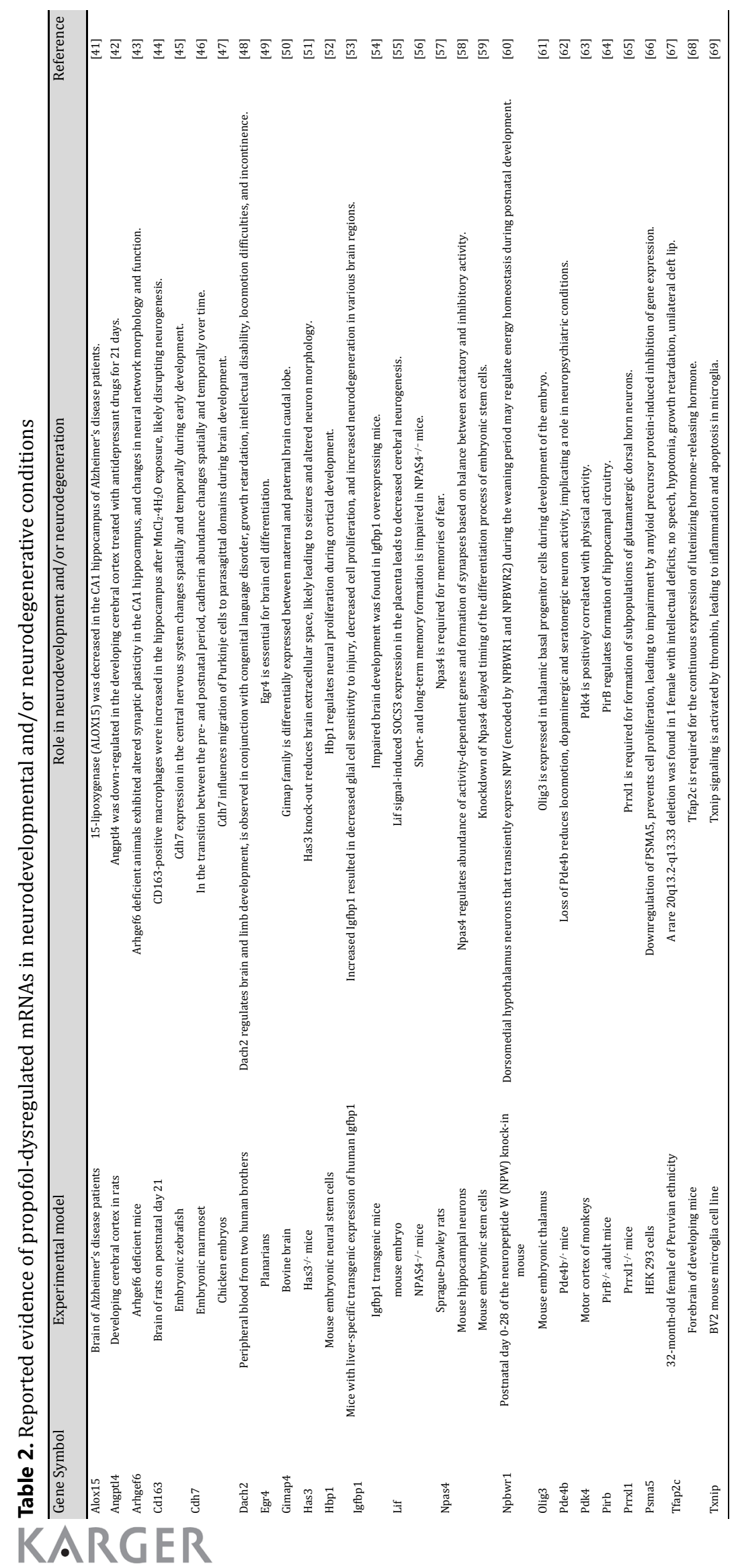


neurotoxic effects of anesthetics, novel mechanisms, and neuroprotective strategies. Propofol has recently been observed to decrease cervical carcinoma cell proliferation. Propofol also inhibited the migration of Hela cells possibly via the mechanisms of the reduced organization and decreased intensity of F-actin (the most important component of the cytoskeleton) [34]. These pathway analyses are helpful in contributing to greater mechanistic understanding the conserved across various physiological processes occurred in different types of cells following propofol treatment.

Our results showed that propofol elicited downregulation of 33 mRNAs and upregulation of 67 mRNAs (Fig. 2). IPA bioinformatics analysis indicates that some of these altered mRNAs are linked to apoptosis, autophagy, calcium handling, neurotrophin expression, neuronal morphology, and phenotypes (Fig. 5). For example, propofol-induced upregulation of interleukin-2-inducible T-cell kinase may be involved in acute calcium increase reported following anesthetic exposure, as previous literature proposed its involvement in the calcium-related and neuroprotective inflammatory response [35, 36]. Our mRNA array also found that oligodendrocyte factor 3 (oligo3) was downregulated by propofol. Since oligo3 influences neuron fate specification during the period of neurogenesis, propofol may alter neuron development and outgrowth, leading to altered synaptic plasticity and/or neural network formation. Existing information on the role of these genes in these non-anesthetic neurodegenerative conditions is extremely valuable in providing new insights on potential phenotypes related to anesthetic-induced neurotoxicity.

IncRNAs can be classified as antisense, intergenic, overlapping, intronic, and bidirectional with respect to their nearby protein-coding genes. The mechanisms of lncRNA action are complex and they can either regulate transcription machinery, chromatin modeling complexes, as well as mRNA and protein expression [37]. Our microarray data show upregulation of 107 lncRNA and downregulation of 52 lncRNA following propofol exposure. These altered lncRNAs belong to five categories of $\operatorname{lncRNAs}$ and over $50 \%$ of these lncRNAs were intergenic IncRNAs. Thus, these multiple types of dysregulated lncRNAs suggest possible various mechanisms of IncRNA action on propofol-induced neurotoxicity (Fig. 4).

Though unlikely due to the accompanying increased abundance of 107 lncRNAs and a decrease in 52 lncRNAs alone, the lncRNA and mRNA interactions likely play large roles in the downstream neuroapoptosis observed and other adverse effects reported. Bioinformatics analysis demonstrated the extensive signaling pathways and networks between dysregulated lncRNA and mRNAs that may be related to initiation and/or progression of propofol-induced neurotoxicity. Major IncRNA-involved pathways were apoptosis, neuronal morphology, calcium release, synaptic plasticity, and neurotrophin expression (Fig. 6 and Supplementary Figs. S1 and S2). For example, Gm11985-Igfbp1 (insulin growth factor binding protein 1), one of IncRNA and its nearby coding mRNA pair as shown in Table 1, was downregulated and upregulated, respectively in the propofol-treated hippocampus. Igfbp1 was reported to be elevated during various other kinds of brain injuries, such as hypoxic ischemia in rats [38] and multiple sclerosis in humans [39]. It is believed that insulin growth factor (Igf)/ Igfbp1 axis is strongly implicated in brain injury, and Igfbp protein helps maintain Igf protein at the local brain injury site, thus playing a neuroprotective role [40]. However, the function of Gm11985 was barely studied before. Consistent with our data, it is possible that the propofol-induced downregulation of Gm11985 (chromosome 11: 7183156-7188569, negative strand) might lead to an increased level of its nearby downstream antisense Igfbp1 mRNA (Chrosome11: 7197786-7202546, positive strand) by complementary binding, in order to prevent neuronal cell damage conferred by propofol.

\section{Conclusion}

Collectively, this microarray analysis to investigate the abnormal profile of lncRNAs and mRNAs in the mouse hippocampus following propofol exposure is a new angle to explore in anesthetic-induced neurotoxicity. These dozens of changed lncRNAs and mRNAs

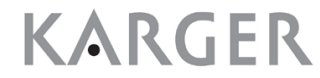




\section{Cellular Physiology Cell Physiol Biochem 2018;49:2496-2510 and Biochemistry \begin{tabular}{l|l} 
DOI: 10.1159/000493875 & O 2018 The Author(s). Published by S. Karger AG, Basel \\
Publisned & www.karger.com/cpb
\end{tabular}

might interact in extensive signaling networks linked to multiple downstream disease phenotypes. These disease phenotypes not only include the widely recognized anestheticinduced neuroapoptosis, but also other neurological outcomes (e.g., neuron morphology, myelination, and synaptic plasticity). In addition, these phenotypes might be related to complex mechanisms such as calcium release, neurotrophin expression, or autophagy. The roles of IncRNAs have just begun to be explored in the field of anesthetic-induced neurotoxicity. Our data provide insights into novel molecular mechanisms of anestheticinduced developmental neurodegeneration and preventive strategies. In addition, this study provides a starting point for us and other researchers to study functional roles and novel molecular mechanisms of lncRNAs underlying developmental neurotoxicity.

\section{Acknowledgements}

This work was supported by grant R01 GM112696 from the National Institutes of Health (to Dr. Xiaowen Bai).

\section{Disclosure Statement}

The authors declare no competing interests.

\section{References}

1 Kajimoto M, Atkinson DB, Ledee DR, Kayser EB, Morgan PG, Sedensky MM, Isern NG, Des Rosiers C, Portman MA: Propofol compared with isoflurane inhibits mitochondrial metabolism in immature swine cerebral cortex. J Cereb Blood Flow Metab 2014;34:514-521.

-2 Yang B, Liang G, Khojasteh S, Wu Z, Yang W, Joseph D, Wei H: Comparison of neurodegeneration and cognitive impairment in neonatal mice exposed to propofol or isoflurane. PLoS One 2014;9:e99171.

-3 Popic J, Pesic V, Milanovic D, Todorovic S, Kanazir S, Jevtovic-Todorovic V, Ruzdijic S: Propofol-induced changes in neurotrophic signaling in the developing nervous system in vivo. PLoS One 2012;7:e34396.

4 Creeley C, Dikranian K, Dissen G, Martin L, Olney J, Brambrink A: Propofol-induced apoptosis of neurones and oligodendrocytes in fetal and neonatal rhesus macaque brain. Br J Anaesth 2013;110:i29-38.

5 Tagawa T, Sakuraba S, Kimura K, Mizoguchi A: Sevoflurane in combination with propofol, not thiopental, induces a more robust neuroapoptosis than sevoflurane alone in the neonatal mouse brain. J Anesth 2014;28:815-820.

6 Guoa P, Huangb Z, Taoa T, Chen X, Zhang W, Zhang Y, Lin C: Zebrafish as a model for studying the developmental neurotoxicity of propofol. J Appl Toxicol 2015;35:1511-1519.

7 Yan Y, Qiao S, Kikuchi C, Zaja I, Logan S, Jiang C, Arzua T, Bai X: Propofol induces apoptosis of neurons but not astrocytes, oligodendrocytes, or neural stem cells in the neonatal mouse hippocampus. Brain Sci 2017;7:pii:E130.

8 Wagner M, Ryu YK, Smith SC, Patel P, Mintz CD: Review: effects of anesthetics on brain circuit formation. J Neurosurg Anesthesiol 2014;26:358-362.

9 Shen X, Liu Y, Xu S, Zhao Q, Guo X, Shen R, Wang F: Early life exposure to sevoflurane impairs adulthood spatial memory in the rat. Neurotoxicology 2013;39:45-56.

10 Stratmann G, Sall JW, May LD, Bell JS, Magnusson KR, Rau V, Visrodia KH, Alvi RS, Ku B, Lee MT, Dai R: Isoflurane differentially affects neurogenesis and long-term neurocognitive function in 60-day-old and 7-day-old rats. Anesthesiology 2009;110:834-848.

11 Jevtovic-Todorovic V, Hartman RE, Izumi Y, Benshoff ND, Dikranian K, Zorumski CF, Olney JW, Wozniak DF: Early exposure to common anesthetic agents causes widespread neurodegeneration in the developing rat brain and persistent learning deficits. J Neurosci 2003;23:876-882.

12 Bosnjak Z, Logan S, Liu Y, Bai X: Recent insights into molecular mechanisms of propofol-induced developmental neurotoxicity. Anesth Analg 2016;286-296. 


\section{Cellular Physiology Cell Physiol Biochem 2018;49:2496-2510 and Biochemistry \begin{tabular}{l|l} 
DOI: 10.1159/000493875 & (c) 2018 The Author(s). Published by S. Karger AG, Basel \\
www.karger.com/cpb
\end{tabular}

13 Huang J, Jing S, Chen X, Bao X, Du Z, Li H, Yang T, Fan X: Propofol administration during early postnatal life suppresses hippocampal neurogenesis. Mol Neurobiol 2016;53:1031-1044.

-14 Sall JW, Stratmann G, Leong J, Woodward E, Bickler PE: Propofol at clinically relevant concentrations increases neuronal differentiation but is not toxic to hippocampal neural precursor cells in vitro. Anesthesiology 2012;117:1080-1090.

15 Popic J, Pesic V, Milanovic D, Loncarevic-Vasiljkovic N, Smiljanic K, Kanazir S, Ruzdijic S: Induction of TNFalpha signaling cascade in neonatal rat brain during propofol anesthesia. Int J Dev Neurosci 2015;44:22-32.

-16 Engelhardt T, MacDonald J, Galley HF, Webster NR: Selective phosphodiesterase 5 inhibition does not reduce propofol sedation requirements but affects speed of recovery and plasma cyclic guanosine 3 ',5 '-monophosphate concentrations in healthy volunteers. Anesth Analg 2005;101:1050-1053.

17 Kahraman S, Zup SL, McCarthy MM, Fiskum G: GABAergic mechanism of propofol toxicity in immature neurons. J Neurosurg Anesthesiol 2008;20:233-240.

$>18$ Twaroski DM, Yan Y, Zaja I, Clark E, Bosnjak ZJ, Bai X: Altered mitochondrial dynamics contributes to propofol-induced cell death in human stem cell-derived neurons. Anesthesiology 2015;123:1067-1083.

19 Twaroski DM, Yan Y, Olson JM, Bosnjak ZJ, Bai X: Down-regulation of microRNA-21 is involved in the propofol-induced neurotoxicity observed in human stem cell-derived neurons. Anesthesiology 2014;121:786-800.

20 Xu Z, Yu J, Wu J, Qi F, Wang H, Wang Z, Wang Z: The effects of two anesthetics, propofol and sevoflurane, on liver ischemia/reperfusion injury. Cell Physiol Biochem 2016;38:1631-1642.

21 Deng F, Wang S, Zhang L, Xie X, Cai S, Li H, Xie GL, Miao HL, Yang C, Liu X, Xia Z: Propofol Through Upregulating Caveolin-3 Attenuates Post-Hypoxic Mitochondrial Damage and Cell Death in H9C2 Cardiomyocytes During Hyperglycemia. Cell Physiol Biochem 2017;44:279-292.

22 Wu H, Yang L, Chen LL: The diversity of long noncoding RNAs and their Generation. Trends Genet 2017;33:540-552.

-23 Ng SY, Johnson R, Stanton LW: Human long non-coding RNAs promote pluripotency and neuronal differentiation by association with chromatin modifiers and transcription factors. EMBO J 2012;31:522533.

24 Zheng X, Lin C, Li Y, Ye J, Zhou J, Guo P: Long noncoding RNA BDNF-AS regulates ketamine-induced neurotoxicity in neural stem cell derived neurons. Biomed Pharmacother 2016;82:722-728.

25 Samuelsen GB, Larsen KB, Bogdanovic N, Laursen H, Graem N, Larsen JF, Pakkenberg B: The changing number of cells in the human fetal forebrain and its subdivisions: a stereological analysis. Cereb Cortex 2003;13:115-122.

26 Cattano D, Young C, Straiko MM, Olney JW: Subanesthetic doses of propofol induce neuroapoptosis in the infant mouse brain. Anesth Analg 2008;106:1712-1714.

27 Kramer A, Green J, Pollard J, Jr., Tugendreich S: Causal analysis approaches in Ingenuity Pathway Analysis. Bioinformatics 2014;30:523-530.

28 Liao Q Liu C, Yuan X, Kang S, Miao R, Xiao H, Zhao G, Luo H, Bu D, Zhao H, Skogerbo G, Wu Z, Zhao Y: Largescale prediction of long non-coding RNA functions in a coding-non-coding gene co-expression network. Nucleic Acids Res 2011;39:3864-3878.

-29 Subramanian A, Tamayo P, Mootha VK, Mukherjee S, Ebert BL, Gillette MA, Paulovich A, Pomeroy SL, Golub TR, Lander ES, Mesirov JP: Gene set enrichment analysis: a knowledge-based approach for interpreting genome-wide expression profiles. Proc Natl Acad Sci U S A 2005;102:15545-15550.

30 Pearn ML, Hu Y, Niesman IR, Patel HH, Drummond JC, Roth DM, Akassoglou K, Patel PM, Head BP: Propofol neurotoxicity is mediated by p75 neurotrophin receptor activation. Anesthesiology 2012;116:352-361.

31 Dholakia U, Clark-Price SC, Keating SCJ, Stern AW: Anesthetic effects and body weight changes associated with ketamine-xylazine-lidocaine administered to CD-1 mice. PLoS One 2017;12:e0184911.

-32 Briner A, Nikonenko I, De Roo M, Dayer A, Muller D, Vutskits L: Developmental stage-dependent persistent impact of propofol anesthesia on dendritic spines in the rat medial prefrontal cortex. Anesthesiology 2011;115:282-293.

-33 Liu Y, Yan Y, Inagaki Y, Logan S, Bosnjak ZJ, Bai X: Insufficient astrocyte-derived brain-derived neurotrophic factor contributes to propofol-induced neuron death through Akt/glycogen synthase kinase 3beta/ mitochondrial fission pathway. Anesth Analg 2017;125:241-254.

-34 Zhang F, Wang C, Cui Y, Li S, Yao Y, Ci Y, Wang J, Hou W, Wu A, Li E: Effects of propofol on several membrane characteristics of cervical cancer cell lines. Cell Physiol Biochem 2016;40:172-182. 


\section{Cellular Physiology Cell Physiol Biochem 2018;49:2496-2510 and Biochemistry \begin{tabular}{l|l} 
DOI: 10.1159/000493875 & (c) 2018 The Author(s). Published by S. Karger AG, Basel \\
www.karger.com/cpb
\end{tabular}

-35 Zhong Y, Johnson AJ, Byrd JC, Dubovsky JA: Targeting Interleukin-2-Inducible T-cell Kinase (ITK) in T-Cell Related Diseases. Postdoc J 2014;2:1-11.

-36 Kannan AK, Kim DG, August A, Bynoe MS: Itk signals promote neuroinflammation by regulating CD4+ T-cell activation and trafficking. J Neurosci 2015;35:221-233.

-37 Rinn JL, Chang HY: Genome regulation by long noncoding RNAs. Annu Rev Biochem 2012;81:145-166.

-38 Beilharz EJ, Russo VC, Butler G, Baker NL, Connor B, Sirimanne ES, Dragunow M, Werther GA, Gluckman PD, Williams CE, Scheepens A: Co-ordinated and cellular specific induction of the components of the IGF/ IGFBP axis in the rat brain following hypoxic-ischemic injury. Brain Res Mol Brain Res 1998;59:119-134.

39 Gveric D, Cuzner ML, Newcombe J: Insulin-like growth factors and binding proteins in multiple sclerosis plaques. Neuropathol Appl Neurobiol 1999;25:215-225.

-40 Venters HD, Broussard SR, Zhou JH, Bluthe RM, Freund GG, Johnson RW, Dantzer R, Kelley KW: Tumor necrosis factor(alpha) and insulin-like growth factor-I in the brain: is the whole greater than the sum of its parts? J Neuroimmunol 2001;119:151-165.

41 Bazan NG: Cellular and molecular events mediated by docosahexaenoic acid-derived neuroprotectin D1 signaling in photoreceptor cell survival and brain protection. Prostaglandins Leukot Essent Fatty Acids 2009;81:205-211.

-42 Tsapakis EM, Fernandes C, Moran-Gates T, Basu A, Sugden K, Aitchison KJ, Tarazi FI: Effects of antidepressant drug exposure on gene expression in the developing cerebral cortex. Synapse 2014;68:209220.

43 Ramakers GJ, Wolfer D, Rosenberger G, Kuchenbecker K, Kreienkamp HJ, Prange-Kiel J, Rune G, Richter K, Langnaese K, Masneuf S, Bosl MR, Fischer KD, Krugers HJ, Lipp HP, van Galen E, Kutsche K: Dysregulation of Rho GTPases in the alphaPix/Arhgef6 mouse model of X-linked intellectual disability is paralleled by impaired structural and synaptic plasticity and cognitive deficits. Hum Mol Genet 2012;21:268-286.

44 Abe H, Ohishi T, Nakane F, Shiraki A, Tanaka T, Yoshida T, Shibutani M: Exposure to MnCl2. 4H2O during development induces activation of microglial and perivascular macrophage populations in the hippocampal dentate gyrus of rats. J Appl Toxicol 2015;35:529-535.

45 Liu B, Joel Duff R, Londraville RL, Marrs JA, Liu Q: Cloning and expression analysis of cadherin7 in the central nervous system of the embryonic zebrafish. Gene Expr Patterns 2007;7:15-22.

46 Matsunaga E, Nambu S, Oka M, Iriki A: Complex and dynamic expression of cadherins in the embryonic marmoset cerebral cortex. Dev Growth Differ 2015;57:474-483.

47 Luo J, Treubert-Zimmermann U, Redies C: Cadherins guide migrating Purkinje cells to specific parasagittal domains during cerebellar development. Mol Cell Neurosci 2004;25:138-152.

48 Zhang Y, Liu Y, Li Y, Duan Y, Zhang K, Wang J, Dai Y: Exome sequencing identifies mutations in ABCD1 and DACH2 in two brothers with a distinct phenotype. BMC Med Genet 2014;15:105.

49 Fraguas S, Barberan S, Iglesias M, Rodriguez-Esteban G, Cebria F: egr-4, a target of EGFR signaling, is required for the formation of the brain primordia and head regeneration in planarians. Development 2014;141:1835-1847.

50 Chamberlain AJ, Vander Jagt CJ, Hayes BJ, Khansefid M, Marett LC, Millen CA, Nguyen TT, Goddard ME: Extensive variation between tissues in allele specific expression in an outbred mammal. BMC Genomics 2015;16:993.

51 Arranz AM, Perkins KL, Irie F, Lewis DP, Hrabe J, Xiao F, Itano N, Kimata K, Hrabetova S, Yamaguchi Y: Hyaluronan deficiency due to Has3 knock-out causes altered neuronal activity and seizures via reduction in brain extracellular space. J Neurosci 2014;34:6164-6176.

52 Watanabe N, Kageyama R, Ohtsuka T: Hbp1 regulates the timing of neuronal differentiation during cortical development by controlling cell cycle progression. Development 2015;142:2278-2290.

53 Doublier S, Duyckaerts C, Seurin D, Binoux M: Impaired brain development and hydrocephalus in a line of transgenic mice with liver-specific expression of human insulin-like growth factor binding protein-1. Growth Horm IGF Res 2000;10:267-274.

54 Ni W, Rajkumar K, Nagy JI, Murphy LJ: Impaired brain development and reduced astrocyte response to injury in transgenic mice expressing IGF binding protein-1. Brain Res 1997;769:97-107.

55 Tsukada T, Simamura E, Shimada H, Arai T, Higashi N, Akai T, Iizuka H, Hatta T: The suppression of maternal-fetal leukemia inhibitory factor signal relay pathway by maternal immune activation impairs brain development in mice. PLoS One 2015;10:e0129011. 


\section{Cellular Physiology Cell Physiol Biochem 2018;49:2496-2510

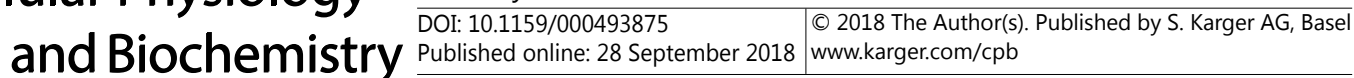 \\ Bai et al.: IncRNAs and Propofol Developmental Neurotoxicity}

56 Ramamoorthi K, Fropf R, Belfort GM, Fitzmaurice HL, McKinney RM, Neve RL, Otto T, Lin Y: Npas4 regulates a transcriptional program in CA3 required for contextual memory formation. Science 2011;334:16691675.

57 Ploski JE, Monsey MS, Nguyen T, DiLeone RJ, Schafe GE: The neuronal PAS domain protein 4 (Npas4) is required for new and reactivated fear memories. PLoS One 2011;6:e23760.

$\$ 58$ Lin Y, Bloodgood BL, Hauser JL, Lapan AD, Koon AC, Kim TK, Hu LS, Malik AN, Greenberg ME: Activitydependent regulation of inhibitory synapse development by Npas4. Nature 2008;455:1198-1204.

\$59 Klaric TS, Thomas PQ, Dottori M, Leong WK, Koblar SA, Lewis MD: A reduction in Npas4 expression results in delayed neural differentiation of mouse embryonic stem cells. Stem Cell Res Ther 2014;5:64.

60 Motoike T, Skach AG, Godwin JK, Sinton CM, Yamazaki M, Abe M, Natsume R, Sakimura K, Yanagisawa M: Transient expression of neuropeptide $\mathrm{W}$ in postnatal mouse hypothalamus--a putative regulator of energy homeostasis. Neuroscience 2015;301:323-337.

61 Wang L, Bluske KK, Dickel LK, Nakagawa Y: Basal progenitor cells in the embryonic mouse thalamus - their molecular characterization and the role of neurogenins and Pax6. Neural Dev 2011;6:35.

62 Siuciak JA, McCarthy SA, Chapin DS, Martin AN: Behavioral and neurochemical characterization of mice deficient in the phosphodiesterase-4B (PDE4B) enzyme. Psychopharmacology (Berl) 2008;197:115-126.

63 Mitchell AC, Leak RK, Garbett K, Zigmond MJ, Cameron JL, Mirnics K: Physical activity-associated gene expression signature in nonhuman primate motor cortex. Obesity (Silver Spring) 2012;20:692-698.

64 Ukai H, Kawahara A, Hirayama K, Case MJ, Aino S, Miyabe M, Wakita K, Oogi R, Kasayuki M, Kawashima S, Sugimoto S, Chikamatsu K, Nitta N, Koga T, Shigemoto R, Takai T, Ito I: PirB regulates asymmetries in hippocampal circuitry. PLoS One 2017;12:e0179377.

65 Rebelo S, Reguenga C, Lopes C, Lima D: Prrxl1 is required for the generation of a subset of nociceptive glutamatergic superficial spinal dorsal horn neurons. Dev Dyn 2010;239:1684-1694.

66 Wu Y, Zhang S, Xu Q, Zou H, Zhou W, Cai F, Li T, Song W: Regulation of global gene expression and cell proliferation by APP. Sci Rep 2016;6:22460.

67 Butler MG, Usrey KM, Roberts JL, Manzardo AM, Schroeder SR: 20q13.2-q13.33 deletion syndrome: A case report. J Pediatr Genet 2013;2:157-161.

68 Kramer PR, Krishnamurthy R, Mitchell PJ, Wray S: Transcription factor activator protein-2 is required for continued luteinizing hormone-releasing hormone expression in the forebrain of developing mice. Endocrinology 2000;141:1823-1838.

69 Ye X, Zuo D, Yu L, Zhang L, Tang J, Cui C, Bao L, Zan K, Zhang Z, Yang X, Chen H, Tang H, Zu J, Shi H, Cui G: ROS/TXNIP pathway contributes to thrombin induced NLRP3 inflammasome activation and cell apoptosis in microglia. Biochem Biophys Res Commun 2017;485:499-505. 